inOedia $\quad \begin{aligned} & \text { InMedia } \\ & \text { The French Journal of Media Studies }\end{aligned}$

5 | 2014

Media and Diversity

\title{
Media and Diversity: A Century-Long Perspective on an Enlarged and Internationalized Field of Research
}

Christine Larrazet and Isabelle Rigoni

\section{(2) OpenEdition \\ Journals}

Electronic version

URL: http://journals.openedition.org/inmedia/747

DOI: $10.4000 /$ inmedia.747

ISSN: 2259-4728

Publisher

Center for Research on the English-Speaking World (CREW)

\section{Electronic reference}

Christine Larrazet and Isabelle Rigoni, « Media and Diversity: A Century-Long Perspective on an Enlarged and Internationalized Field of Research », InMedia [Online], 5 | 2014, Online since 17 October 2014, connection on 10 December 2020. URL : http://journals.openedition.org/inmedia/747 ; DOI : https://doi.org/10.4000/inmedia.747

This text was automatically generated on 10 December 2020.

(c) InMedia 


\title{
Media and Diversity: A Century- Long Perspective on an Enlarged and Internationalized Field of Research
}

\author{
Christine Larrazet and Isabelle Rigoni
}

1 What is the influence of the mass media on the social cohesion of diverse societies? Do the mass media contribute to hindering or damaging relationships between the social groups composing diversified societies - be it in terms of "race", ethnicity, culture or gender? Or, on the contrary, can they improve it? For nearly a century these questions have penetrated the academic and political spheres of numerous countries at various times and in various social and political situations but with a constant resurgence up to the point of delineating a large internationalized area of research.

2 Anglo-Saxon countries have been one step ahead on this issue, in particular the United States, where, in the very early days of sociology and communication sciences, scholars investigated the link between mass media and interracial and intercultural relationships. While contributing to the reflection on "Americanization", Robert Ezra Park first inaugurated this specialized field by furnishing an in-depth documentation of the foreign-language press, and its role in encouraging or hindering new immigrants to become Americans. ${ }^{1}$ In 1946, Bernard Berelson, the founding father of content analysis, delved with another researcher into hundreds of pieces of popular fiction appearing in mass magazines to determine what kinds of people appeared in short stories in terms of their racial, religious, and national backgrounds, and how they were treated, with the ambition to investigate the existence and nature of differential treatment accorded to various ethnic groups. Their content analysis revealed that the "100\% Americans", whom they defined as "people of 'pure American stock' - white, Protestant, AngloSaxons", were better treated, quantitatively and qualitatively, than minorities, in which category they included American Negroes, Jews, Mexicans, Italian-Americans, Japanese-Americans, and Irish-Americans. ${ }^{2}$ In 1947, Paul Lazarsfeld, renowned as the 
father of sophisticated studies of mass communications, investigated the concept of "Tolerance Propaganda" and discussed its assumption that mass media like radio and newspapers could promote friendly relations between racial groups. "If we can sell soap this way, why shouldn't we also be able to sell good interracial relations?" he wondered, before identifying the different shortcomings or risks of this idealistic perception, one of the major ones being that such propaganda might have a boomerang effect that would reinforce the intolerance of those having structured discriminatory attitudes. ${ }^{3}$ If media were to voluntarily help improve interracial and intercultural relationships, they would have to be backed up by other institutions such as the government or local associations.

3 After these early studies, analysis of the representation of ethnic minorities and of racism in the mainstream media gained a new force through the impetus of the Kerner Report, which investigated the causes at the roots of repeated riots in the ghettos from 1965 to 1968 , and which unexpectedly devoted a specific chapter to the responsibility of the news media in the division of American society into two societies, black and white, separate and unequal. ${ }^{4}$ Since then, numerous American studies on media representation of minorities, which has become an established academic research field in the second part of the 20th century, have revealed a tension between the producers of news - the large majority belonging to the white community - and minorities. In spite of real progress, especially since the civil rights movement, stereotypes that white citizens harbored about Americans of color still affected the content of news at the end of the century, and the general lack of coverage of minority communities contributed to a sense of "otherness" about Americans of color, one that induced the audience not to regard them as regular citizens. From the 1960 s to the 2000s, most researchers drew the conclusion that by failing to reflect the diversified composition of societies and by fueling misrepresentations of minorities, mass media fed the social distance that separates different groups already distanced by de facto segregation.

After nearly 40 years of theoretical and practical progress in the United States, this seminal field of research has developed in many places throughout the world, and the publication of books on the differential treatment accorded to minorities reveals dynamic scientific activity at the international level. At the beginning of the 21st century, books have been published in the United States, Great Britain, Canada, Australia, Israel, France, Germany and Finland. Since historians have shown the media's role in developing the national narrative and the perpetuation of national identity, the media are now commonly acknowledged as major actors when dealing with identity construction, social and national cohesion as well as citizenship. We now know the way in which the mass media have played a major role in imagining (national) community/ies. While standardizing popular ideologies, media help nationalize culture as it was contextualized in the frame of the emerging nation state. Political scientists and sociologists seek to emphasize the importance of the media in terms of social cohesion at a time of institutional recognition of diversity and discrimination. Specialists in international communications have unraveled processes of identity construction throughout media production as well as media consumption and the appropriation of communication technologies in everyday life. 


\section{A Fast-Growing Ethnic Media Production}

5 The first and major line of inquiry - the invisibility, underrepresentation and misrepresentation of minorities in the mainstream news media - which developed first in the United States, before reaching other countries such as Canada or Great Britain has been consolidated by further avenues of research. The large internationalized field of "Media and Minorities" has gone beyond this first dimension and now comprises complementary inquiries. Multidisciplinary approaches on the media have revealed that alongside mainstream media coexist a multitude of media productions led by ethnic and religious groups which, both by their existence and by the positions they take, contribute to a redefinition of national identity, minority groups' identities and individual identities. Migrants and ethnic minorities have a long tradition of establishing ethnic media, which were first created in the 19th century in North America and in some Western European countries. ${ }^{5}$ Academics highlighted their role in furthering and supporting democracy and participating in the public sphere, as well as strong vectors of collective representation and mobilization. More recently, due to their extensive use of information and communication technologies (ICT), ethnic media have been described as indicators of transnational and transcultural ways of life. The orientation and production of ethnic media must ultimately be understood within a transnational field of informational flow, diasporic/identity engagement and self(re)presentation. Despite the still ongoing digital divide, the widespread use of ICT and the advent of Web 2.0 have particularly amplified the expression of cultural and religious actors, in the sense that they have introduced new facilities and new tools. Rich sociological works on the electronic media of ethnic minorities and diaspora show that we are witnessing the emergence of new forms of living together at the same time as new forms of identity representation. The Internet has become, for minorities and diasporas, both a means of group representation and a mode of intervention in public debate.

\section{A Favorable Supranational Context on Diversity and/in the Media}

6 At the turn of the millennium, with the UNESCO Universal Declaration on Cultural Diversity of 2001, the already extended field of "Media and Minorities" has been extended again to new frontiers. The UNESCO declaration - unanimously adopted at the first ministerial-level meeting to be held after September 11 - was an opportunity for States to "reaffirm their conviction that intercultural dialogue is the best guarantee of peace and to reject outright the theory of the inevitable clash of cultures and civilisations". ${ }^{6}$ In this political, philosophical and epistemological evolution towards a greater recognition of diversity, the mass media have become considered one of the key targets of the actions taken by supranational organizations playing a delicate role of providing incentives and encouragement for more inclusive media content. In its action program, UNESCO pays a particular attention to the role of the media in the preservation and promotion of cultural diversity in the context of globalization. The Council of Europe has also repeatedly underlined the role of the media in the promotion of cultural diversity, be they traditional media or "new media" benefiting from the development and popularization of ICT. ${ }^{7}$ The Framework Convention of the 
Council of Europe for the Protection of National Minorities (FCNM) in particular demonstrates the strong linkage between the goals of promoting tolerance, social cohesion and cultural diversity, and the instrumental importance of the media in respect of each goal. From the 2000s on, the objective of promoting cultural diversity in respect of the media (including digital) environment became a priority. New information technologies are particularly mentioned in terms of encouraging the production, safeguarding and dissemination of diversified content in the media.

7 The long-researched field of "Media and Minorities" - which first focused on the intranational visibility or invisibility of minorities, ethnic minorities in particular, and more widely on the representation of diversity - has thus been recently enlarged by questioning on "media and cultural diversity". This themed issue of InMedia aims at painting an internationalized panorama of this enlarged and dynamic field of research. To illustrate and nourish this extended area of research, named here "Media and Diversity", this issue provides a multidisciplinary approach and comparative perspectives, with contributions coming from diverse disciplines, including political sciences, sociology, or science and communication studies, and analysis of different countries or areas (Canada, Spain, Portugal, the United States and the European Community). In the process, it draws out the links among the diverse methodologies and theoretical frameworks employed in case studies, and brings out the points of concordance among the results attained in different countries. Five contributions to the field have been organized according to the three main points of view from which we consider the problem is being approached: Mainstream Media and Minorities; Ethnic Media - Role and Production; and Media and Cultural Diversity.

\section{Mainstream Media and Minorities}

8 To correct and improve minorities' visibility in terms of both quantity and quality, one solution envisaged and implemented by news media professionals in the Anglo-Saxon countries has been to hire minority journalists at the level of minority representation in society. In the United States, Canada or Great Britain, it is now commonly accepted that all members of society must participate in the democratic process of which, needless to say, the media are a major component, and that a comprehensive and fair representation of society requires the inclusion of ethnic, racial and gender diversity in the content of news and among media personnel. Part of the research conducted in "Media and Diversity" is therefore questioning the diversification effect. Does the diversification of media personnel, be it in newsrooms (for news media) or among creators and producers (for entertainment media), have a noticeable impact on media content? Is it sufficient? Does minority staffing increase community audiences and/or improve minority readers' trust?

In this set of questioning on the diversification effect, Bradley Clark used a participant observer methodology to analyze a Canadian Broadcasting Corporation (CBC) news and current affairs operation with the ambition to unveil the influence of production norms and long-held news values on the coverage of minority groups. His study, which examines the forces that shape news content at its principal site of production, i.e. the newsroom, reveals that corporate culture, hiring diverse staff, and the deployment of more resources can all work to bring diversity to news content. However, Clark observes that more inclusive journalism remains sporadic, as mainstream bias pervades 
newsgathering routines. Clark provides a detailed analysis that supports Augie Fleras's contention that the challenge of reforming media coverage of minority groups would be the equivalent of "walking up a down escalator". ${ }^{8}$

On the other side of the spectrum of media production, the reception and effects of non-inclusiveness of diversity in the content of news or entertainment, or of its progressive diversification, are investigated. Does non-inclusiveness of diversity or, on the contrary, media content diversification impact interracial, intercultural or gender relationships? Can this impact be assessed and measured? This is what Maria SotoSanfiel, Rosa Palencia Villa and Adriana Ibiti endeavor to address regarding the appreciation of lesbian narratives. Using a mixed-methods approach, providing further proof of the complementariness of both quantitative and qualitative methods, their study explores the effect of manifest sexual orientation and gender on the appreciation of the TV series The L word in Spain, with appreciation being defined as a psychological response to narratives that prompts a profound perception of meaning or a motivation to create reflections or thoughts among audiences. The investigation published here reveals that sexual orientation affects magnitudes of appreciation, while gender does not.

\section{Ethnic Media - Role and Production}

Most of the research on ethnic media has for a long time concerned deprived foreign workers. In this issue, Inês David offers a paper that explores an under-researched topic in the field of ethnic media: initiatives concerning relatively affluent populations. The discussion is based on a mapping of radio initiatives in Portugal and focuses on the role of a local station founded by, and catering for, self-designated "expatriates" residing in the touristic region of the Algarve. The paper problematizes the issues of inclusion/exclusion, voice, transnational connectivity, and cultural reproduction that are central to mediated self-representation in migratory contexts. It suggests the consideration of a category of media pertaining to relatively privileged populations in studies of ethnic media.

Kira Kosnick analyzes some unexpected effects of ethnic media production. Whereas migration and media are often assumed to be primary agents in the intensification of flows of people, ideas, images, and the blurring of boundaries, Kosnick highlights the role of media in regulating migration flows to the EU and the United States. Beyond constructing representations of minorities and migration processes that impact on interethnic relations and politics in countries of immigration, it is argued that media technologies and representations have new roles to play when it comes to targeting potential migrants to prevent mobility across borders, both in the sense of addressing them as audiences in order to discourage migration, and in the sense of noncommunicative technologies that provide data in order to engage in social sorting and identification for the purposes of mobility control and surveillance.

\section{Media and Cultural Diversity}

13 This special issue ends on a paper that enlarges the debate on cultural diversity and the media. Through a decade-long literature review, Mélodine Sommier delivers a study that examines the way culture has been researched in media studies and suggests how 
critical intercultural communication could contribute to the field. Results show that studies dealing with media and culture do not systematically define the concept of culture. Findings also indicate that culture is oftentimes taken for granted instead of being problematized and addressed as a source of struggle. From there, the advantages of using a critical intercultural communication framework to examine culture are discussed.

We hope with this issue to reveal the dynamic dimension of an international area of research that has nearly reached hundred years of age and still has long to live. In a world where most of the populations of democracies are diversified and where major public institutions are forced to deal with issues of ethnic, gender and cultural diversity and with discrimination and racism, this field of research, which questions the relationship, or the absence of relationship, between actors of the media and diverse communities, is becoming increasingly relevant. We thus hope to contribute to fueling this area with new reflections and paths.

\section{BIBLIOGRAPHY}

Adoni, Hanna, Dan Caspi, and Akiba A. Cohen, Media, Minorities, and Hybrid Identities: The Arab and Russian Communities in Israel. Cresskill, N.J.: Hampton Press, 2006.

Anderson, Benedict. Imagined Communities: Reflections on the Origin and Spread of Nationalism. New York: Verso, 1991.

Appadurai, Arjun. Modernity at Large: Cultural Dimensions of Globalization. Minneapolis: University of Minnesota Press, 1991.

Berelson, Bernard, and Patricia J. Salter. "Majority and Minority Americans: An Analysis of Magazine Fiction." Public Opinion Quarterly 10 (1946): 168-190.

Campbell, Christopher. Race, Myth and the News. Thousand Oaks: Sage Publications, 1995.

Cottle, Simon ed.. Ethnic Minorities and the Media. Maidenhead: Open University Press, 2001.

Cunningham, Stuart, and John Sinclair. Floating Lives: The Media and Asian Diasporas. Lanham: Rowman \& Littlefield Publishers, 2001.

Daniel, Jack L., and Anita L Allen. "Newsmagazines, Public Policy, and the Black Agenda." In Discourse and Discrimination, edited by Geneva Smitherman-Donaldson and Teun Van Dijk, 23-45. Detroit: Wayne State University Press, 1988.

Diminescu, Dana. “Le migrant connecté. Pour un manifeste épistémologique." Migrations Société 17(102), (2007): 275-292.

Entman, Robert, and Andrew Rojecki. The Black Image in the White Mind, Media and Race in America. Chicago: University of Chicago Press, 2000.

Fleras, Augie. The Media Gaze: Representations of Diversities in Canada. Vancouver: UBC Press, 2011.

Fleras, Augie, and Jean Lock Kunz. Media and Minorities: Representing Diversity in a Multicultural Canada. Toronto: Thompson Educational Publishing, 2001. 
Geissler, Rainer, and Horst Pöttker. Massenmedien und die Integration ethnischer Minderheiten in Deutschland. Bielefeld: Transcript, 2005.

Gellner, Ernest. Nations and Nationalism. Oxford: Blackwell, 1983.

Georgiou, Myria. Diaspora, Identity and the Media: Diasporic Transnationalism and Mediated Spatialities. New York: Hampton Press, 2006.

Georgiou, Myria, Olga Guedes-Bailey, and R. Harindranatheds.. Transnational Lives and the Media: Reimagining Diasporas. Basingstoke: Palgrave, 2007.

Henry, Frances, and Carol Tator. Discourses of Domination: Racial Bias in the Canadian EnglishLanguage Press. Toronto: University of Toronto Press, 2002.

Hobsbawm, Eric. Nations and Nationalism since 1780: Programme, Myth, Reality. Cambridge: Cambridge University Press, 1990.

Husband, Charles. A Richer Vision. The Development of Ethnic Minority Media in Western Democracies. Paris/London: Unesco/John Libbey, 1994.

Keever, Beverly A., Martindale, Carolyn, and Mary A. Weston. U.S. News Coverage of Racial Minorities, A Sourcebook 1934-1996. Westport, Connecticut: Greenwood Press, 1997.

Kerner Commission. 1968 Report of the National Advisory Commission on Civil Disorders. New York: Pantheon Books, 1988.

Larson Greco, Stephanie. Media and Minorities: The Politics of Race in News and Entertainment. Lanham, Maryland: Rowman \& Littlefield Publishers, 2006.

Law, Ian. Race in the News. New York: Palgrave, 2002.

Lazarsfeld, Paul. "Some Remarks on the Role of the Mass Media in So-Called Tolerance Propaganda." The Journal of Social Issues 3(3) (1947): 17-25.

Licoppe, Christian. “Sociabilité et technologies de communication. Deux modalités d'entretien des liens interpersonnels dans le contexte du déploiement des dispositifs de communication mobiles." Réseaux 112-113 (2002): 172-210.

Macé, Eric. "La fiction télévisuelle française au miroir de The Wire : monstration des minorités, évitement des ethnicités." Réseaux 181 (2013).

Martindale, Carolyn. The White Press and Black America. New York: Greenwood Press, 1986.

Mattelart, Tristan. “TIC et diasporas.” TIC\&Société, special issue 3(1-2) (2009).

McGonagle, Tarlach. Minority Rights, Freedom of Expression and of the Media: Dynamics and Dilemmas. Antwerp: Intersentia, 2011.

Nedelcu, Mihaela. Le migrant online. Nouveaux modèles migratoires à l'ère du numérique. Paris:

L'Harmattan, 2009.

Noiriel, Gérard. A quoi sert l'identité nationale. Paris: Agone, 2007.

Park, Robert E. The Immigrant Press and Its Control. Westport: Greenwood Press, 1970 [1922].

Proulx, Serge. "Des nomades connectés : vivre ensemble à distance.” Hermès (51) (2008): 155-166.

Rigoni, Isabelle ed. Qui a peur de la télévision en couleurs ? La diversité culturelle dans les médias. Montreuil: Aux lieux d'être, 2007.

-. "Les médias des minorités ethniques. Représenter l'identité collective sur la scène publique." Revue européenne des migrations internationales 26(1) (March 2010): 7-16. 
- ed. "Migrants, minorités ethniques et Internet. Usages et représentations." Migrations Société, special issue 22(132) Nov.-Dec. (2010).

Rigoni, Isabelle, and Eugénie Saitta eds. Mediating Cultural Diversity in a Globalised Public Space. Basingstoke: Palgrave Macmillan, 2012.

Robins, Kevin ed. The Challenge of Transcultural Diversities. Transversal Study on the Theme of Cultural Policy and Cultural Diversity. Strasbourg: Council of Europe, Culture and Cultural Heritage Department, 2006.

Sandlund, Tom. Etnicitetsbilden i Finlandssvenska Medier. Helsingfors: Forskningsinstitutet, Svenska social- och kommunalhögskolan vid Helsingfors universitet, 2002.

Stenou, Katérina ed. UNESCO Universal Declaration on Cultural Diversity. A Vision, A Conceptual Platform, A Pool of Ideas for Implementation, A New Paradigm. Paris, UNESCO, 2002.

Titley, Gavan. "Media Transnationalism in Ireland: An Examination of Polish Media Practices." Translocations: The Irish Migration, Race and Social Transformation Review 3(1) (2008): 29-49.

Wieviorka, Michel. Rapport à la ministre de l'Enseignement supérieur et de la Recherche sur la diversité. Paris: Robert Laffont, 2008.

Wilson, Clint C., and Félix Gutierrez. Race, Multiculturalism, and the Media. From Mass to Class Communication. Thousand Oaks: Sage Publications, 1995.

\section{ENDNOTES}

1. Robert E. Park, The Immigrant Press and Its Control. Westport: Greenwood Press, 1970 [1922].

2. Bernard Berelson and Patricia J. Salter. "Majority and Minority Americans: An Analysis of Magazine Fiction," Public Opinion Quarterly 10 (1946), 168.

3. Paul Lazarsfeld, "Some Remarks on the Role of the Mass Media in So-Called Tolerance Propaganda," The Journal of Social Issues 3(3) (1947), 17.

4. Kerner Commission, The 1968 Report of the National Advisory Commission on Civil Disorders (New York: Pantheon Books, 1988), 383.

5. Park, The Immigrant Press; Isabelle Rigoni, ed. "Migrants, minorités ethniques et Internet. Usages et représentations," Migrations Société, special issue 22(132) Nov.-Dec. (2010).

6. Katérina Stenou, ed. UNESCO Universal Declaration on Cultural Diversity. A Vision, A Conceptual Platform, A Pool of Ideas for Implementation, A New Paradigm, Paris, UNESCO, 2002.

7. Tarlach McGonagle. Minority Rights, Freedom of Expression and of the Media: Dynamics and Dilemmas, Antwerp: Intersentia, 2011.

8. Augie Fleras. The Media Gaze: Representations of Diversities in Canada, Vancouver: UBC Press, 2011.

\section{AUTHORS}

\section{CHRISTINE LARRAZET}

Christine Larrazet is an associate professor in American studies at the University of Bordeaux and a researcher at the Emile Durkheim Research Center on comparative sociology and political sciences. She completed a Ph.D. investigating the evolution of the place and representation of black citizens in the content of Time Magazine paralleled with the integration of black journalists in Time's newsrooms from 1965 to 1995. She is currently conducting comparative research on the semantic and political shift of the term "politically correct" as used by the American and French 
public spheres through news media (http://www.durkheim.sciencespobordeaux.fr/PagesCV/ Larrazet.html.

\section{ISABELLE RIGONI}

Isabelle Rigoni is an associate professor in sociology at INS HEA and a researcher at Grhapes. She has been the team leader of the EU Marie Curie excellence project MINORITYMEDIA (6th PCRDT) hosted at Migrinter - University of Poitiers in 2006-10. She has published extensively on media and migration (http://irigoni.blogspot.com/). 